\title{
Hydroclimatic Conditions Preceding the March 2014 Oso Landslide*
}

\author{
Brian Henn, ${ }^{+}$Qian CaO,${ }^{\#}$ Dennis P. LetTenmaier, ${ }^{\#}$ Christopher S. Magirl,${ }^{@}$ \\ Clifford Mass, ${ }^{\&}$ J. Brent Bower, ${ }^{* *}$ Michael St. LaURent, ${ }^{++}$ \\ YIXIN MAO, ${ }^{+}$AND SANJA PERICA ${ }^{++}$ \\ ${ }^{+}$Department of Civil and Environmental Engineering, University of Washington, Seattle, Washington \\ \# Department of Geography, University of California, Los Angeles, Los Angeles, California \\ ${ }^{\circledR}$ U.S. Geological Survey, Tucson, Arizona \\ \& Department of Atmospheric Sciences, University of Washington, Seattle, Washington \\ ** NOAA/National Weather Service, Seattle, Washington \\ ${ }^{++}$Hydrometeorological Design Studies Center, NOAA/National Weather Service, Silver Spring, Maryland
}

(Manuscript received 7 January 2015, in final form 3 March 2015)

\begin{abstract}
The 22 March 2014 Oso landslide was one of the deadliest in U.S. history, resulting in 43 fatalities and the destruction of more than 40 structures. We examine synoptic conditions, precipitation records, and soil moisture reconstructions in the days, months, and years preceding the landslide. Atmospheric reanalysis shows a period of enhanced moisture transport to the Pacific Northwest beginning on 11 February 2014. The 21-42-day periods prior to the landslide had anomalously high precipitation; we estimate that $300-400 \mathrm{~mm}$ of precipitation fell at Oso in the 21 days prior to the landslide. Relative only to historical periods ending on $22 \mathrm{March}$, the return periods of these precipitation accumulations are large (25-88 yr). However, relative to the largest accumulations from any time of the year (annual maxima), return periods are more modest (2-6 yr). In addition to the 2142 days prior to the landslide, there is a secondary maximum in the precipitation return periods for the $4 \mathrm{yr}$ preceding the landslide. Reconstructed soil moisture was also anomalously high prior to the landslide, with return periods relative to the particular day that exceeded $40 \mathrm{yr}$ about a week before the event.
\end{abstract}

\section{Introduction}

On 22 March 2014, a high-mobility landslide was initiated from a 190-m-tall bluff of unconsolidated glacial till and outwash sand $6 \mathrm{~km}$ east of the town of Oso, Washington. The landslide, with an estimated volume of $8 \times$ $10^{6} \mathrm{~m}^{3}$, crossed the entire 1-km-wide North Fork Stillaguamish River floodplain and State Route 530 and covered an area of $1.2 \mathrm{~km}^{2}$ to a depth as great as $20 \mathrm{~m}$ (Iverson et al. 2015). It destroyed over 40 structures in a rural neighborhood and killed 43 people (Keaton et al. 2014). In terms of loss of life, the Oso landslide (also called the SR 530 Landslide by the State of Washington),

\footnotetext{
* Supplemental information related to this paper is available at the Journals Online website: http://dx.doi.org/10.1175/JHM-D-15-0008.s1.

Corresponding author address: Brian Henn, Department of Civil and Environmental Engineering, University of Washington, 201 More Hall, Box 352700, Seattle, WA 98195.

E-mail: bhenn@u.washington.edu
}

was the second worst in U.S. history, surpassed only by the 1985 Mameyes, Puerto Rico, landslide (Jibson 1992).

Landslides from Pleistocene-age bluffs have been widespread along this floodplain (Tabor et al. 2002; Dragovich et al. 2003; Haugerud 2014; Keaton et al. 2014), where unstable deposits of fine-grained lacustrine units at the base are overlain by outwash sand and topped with glacial till, creating conditions conducive to deep-seated landslides and slumps (Thorsen 1989; Miller and Sias 1997; Dragovich et al. 2003). The 2014 Oso landslide initiated from the recurrently active Hazel landslide, which slumped several times in previous decades (Shannon 1952; Benda et al. 1988; Thorsen 1989; Miller and Sias 1997, 1999; Keaton et al. 2014). Analysis of historical precipitation data combined with groundwater modeling (Miller and Sias 1997) indicated that landslide instability is sensitive to $1-\mathrm{yr} \mathrm{cu}-$ mulative precipitation, although Iverson (2000) argued that groundwater pressure distribution is the salient factor in

Publisher's Note: This article was revised on 29 June 2015 to correct a typographical error in the Fig. 1 caption. 


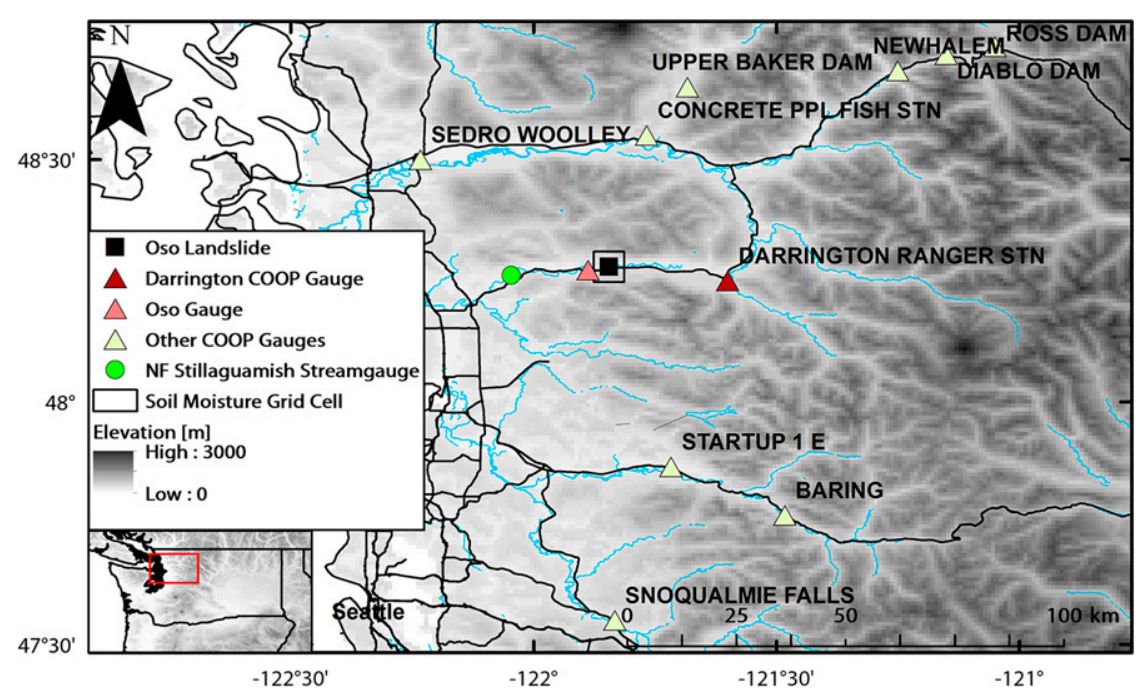

FIG. 1. Area map of the Oso landslide, showing the precipitation gauges, soil moisture model grid cell, and stream gauge used in this study.

triggering large landslides. Because specific linkages between groundwater, rainfall, and slope movements are not clear, analyses from this study cannot directly speak to failure mechanisms and instead indicate that other geophysical factors likely played a role.

The landslide site is characterized by the wet climate of the west slope of the Cascade Range (Fig. 1), where seasonal precipitation maxima normally occur between late fall and late winter. The 2014 Oso landslide came after 6 weeks of heavy rainfall, and others have reported nearby precipitation totals that approached gauge record maxima for 45-day and 4-yr intervals ending in March (Iverson et al. 2015).

We examine the hydroclimatic conditions in the vicinity preceding and at the time of the landslide, using regional synoptic information, historical records of precipitation, and model-reconstructed soil moisture. In so doing, we seek to place the event in a hydroclimatic context. We do not discuss failure mechanisms of the landslide, a topic which we leave to others. Rather, we focus on the synoptic setting, precipitation over time scales from days to years, and soil moisture indicators that may have contributed to local moisture fluxes associated with the landslide.

\section{Methods}

Our source of regional synoptic information was the NOAA Climate Forecast System, version 2 (CFSv2), analysis fields from 1 October 2013 to 22 March 2014. Anomalies were constructed from the CFSv2 reanalysis (CFSR) for 1 October 1980-22 March 2011 (Saha et al. 2010). CFSv2 and CFSR fields are available from the National Climatic Data Center.
Our primary sources of precipitation observations were a gauge at the North Fork Stillaguamish River near Oso (Oso gauge), approximately $3 \mathrm{~km}$ west of the landslide, and the NOAA Cooperative Observer (COOP) gauge located at the Darrington Ranger Station (Darrington gauge) approximately $18 \mathrm{~km}$ to the east of Oso (Fig. 1). The Oso gauge has been operated by the Washington Department of Ecology since 30 October 2011, while the Darrington gauge has been in operation since 1931. The Oso gauge is a Hydrological Services America tipping bucket; the Darrington gauge is an NWS standard 8-in. diameter (nonrecording) rain gauge (SRG). In addition, we identified nine other long-term COOP stations (all SRGs) within a radius of about $80 \mathrm{~km}$ of Oso (Fig. 1) and with homogeneous precipitation frequency distributions, using the criteria of Hosking and Wallis (2005).

We calculated precipitation accumulations for 28 time windows ranging from 1 day to $10 \mathrm{yr}$ [see the supplemental material (SM) for list of windows], with each window ending on 22 March 2014. The 2014 accumulations were compared in two ways: against historical windows ending only on 22 March, and against the largest annual accumulation ending on any day of that water year. For each precipitation gauge site and time window, we fit a probability distribution-the generalized extreme value (GEV) distribution - to the accumulations. Then we compared 2014 accumulations with the fitted distributions to estimate their return periods, with reference to both the 22 March and annual maxima series.

To ensure that our return period calculations were robust, we also carried out a regional frequency analysis using the set of nine gauges plus the Darrington gauge. We created a pooled set of annual maximum precipitation 
accumulations from all sites, with the maxima scaled by mean at the site for each window. Estimating return periods using a pooled sample from multiple sites may help to reduce noise in a single-site analysis.

Soil moisture reconstructions were taken from the University of Washington's Drought Monitoring System for the Pacific Northwest (DMS; www.hydro.washington. edu/forecast/monitor_west), which has a $1 / 16^{\circ}$ latitude and longitude resolution. It provides reconstructed soil moisture in three depth layers from the Variable Infiltration Capacity model (VIC; Liang et al. 1994) for the period 1920-2014, which is an index of conditions relative to climatology, but should not be interpreted as representing specific conditions such as subsurface moisture profiles at the landslide site. We analyzed DMS historical time series of total column soil moisture for the grid cell that encompasses the landslide site (Fig. 1) to determine whether the estimated soil moisture in 2014 was anomalous.

The SM provides greater detail on the approach used to fit probability distributions to the precipitation accumulations (SM1), the regional frequency analysis and the method of estimating return periods at the Oso gauge (SM2), and the hydrologic model used to generate the long-term series of soil moisture (SM3).

\section{Results}

\section{a. Synoptic setting}

Water year 2014 (beginning 1 October 2013) was characterized by two extremes prior to the landslide on 22 March: a period of high pressure and dry conditions in the fall and early winter, followed by an anomalously wet period from mid-February through late March, in which moist, onshore flow dominated. Figure 2 shows the 500-hPa geopotential height, precipitable water, and zonal wind anomalies from climatology (1981-2010) for two periods: from 1 October 2013 to 10 February 2014 (dry) and from 11 February 2014 through the date of the landslide (wet). During the autumn and early winter dry period, a strong positive height anomaly reaching approximately $110 \mathrm{~m}$ was centered over the southern Gulf of Alaska, resulting in enhanced upper-level northerly flow over the west coast of North America (Fig. 2a). The column-total precipitable water for that period was below normal over the western United States (Fig. 2c).

The approximately 6 weeks of wet weather in the Pacific Northwest preceding the landslide were characterized by a different synoptic pattern, with a positive $500-\mathrm{hPa}$ height anomaly of about $60 \mathrm{~m}$ over California and below-normal heights over the north-central Pacific and western Canada (Fig. 2b). The resulting geostrophic wind anomalies were southerly over a large portion of the eastern Pacific and westerly over the Pacific Northwest, a pattern that promoted the advection of tropical and subtropical moisture into the region. The precipitable water anomaly for this period (Fig. 2d) shows a plume of enhanced moisture $\left(2-6 \mathrm{~kg} \mathrm{~m}^{-2}\right)$ extending from Hawaii (Fig. 2d). Zonal wind anomalies show below-normal westerly flow in the early dry period and enhanced westerly flow during the preceding 6 weeks (Figs. 2e,f); increased westerlies enhance upslope flow on the roughly north-south-oriented Cascade Range.

\section{b. Precipitation accumulations}

Precipitation totals (Fig. 3, red lines) immediately ( $<3$ days) prior to the event were light, but in the week prior, totals were $50-150 \mathrm{~mm}$ at most gauges. Cumulative precipitation does not increase greatly as the window is extended to 14 days prior to the event, but it does increase rapidly from 14 to 21 days prior. In the 21 days prior to the landslide, the Oso gauge received $334 \mathrm{~mm}$ of precipitation and the Darrington gauge received $401 \mathrm{~mm}$; 42-day precipitation totals were 506 and $682 \mathrm{~mm}$, respectively. These patterns were consistent across the nine other gauges in the regional group (Fig. 3, gray lines). Precipitation totals increase more slowly as the window is extended to 180 days, reflecting the dry period from 1 October to 10 February in which precipitation was only $60 \%-75 \%$ of normal. At 365 days, however, precipitation totals were at or somewhat above climatological norms. Above-average precipitation accumulations occurred in each water year from 2011 to 2014, despite the anomalously dry start to water year 2014.

\section{c. Precipitation return periods}

Return periods of the 2014 accumulations at Darrington, with reference to historical accumulations ending on 22 March, are shown in Fig. 3 (solid line with squares). The return periods of several years or more indicate that the precipitation leading up to the landslide was unusually heavy for this time of year. The peak return period is for the 21-day window prior to the event (88 yr). We also found large ( $>20 \mathrm{yr}$ ) return periods for the 1745-day windows. As the window is extended to 180 days, return periods decrease because of the earlier dry period, but they also exhibit a second maximum at the 4-yr accumulations window, which has a return period of $9.5 \mathrm{yr}$. Note that for multiyear accumulation windows, sample sizes are reduced as we consider only nonoverlapping multiyear periods prior to the date of the landslide.

Regarding landslide mechanisms, it may be more important to place the precipitation prior to the landslide in the context of heavy precipitation occurring at any time of year, rather than only considering windows ending on 22 March. For Darrington, return periods 

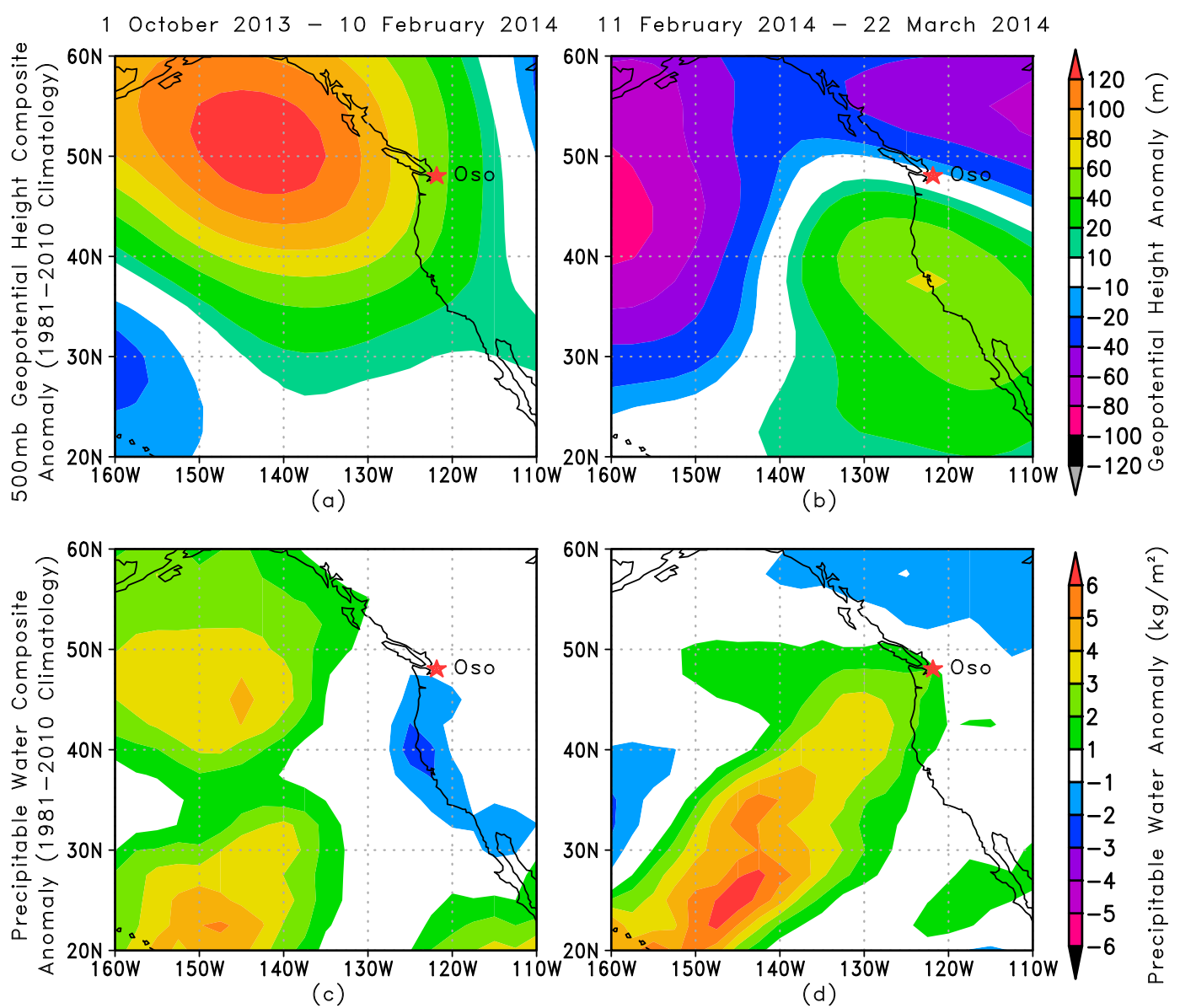

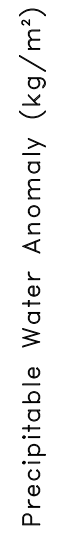
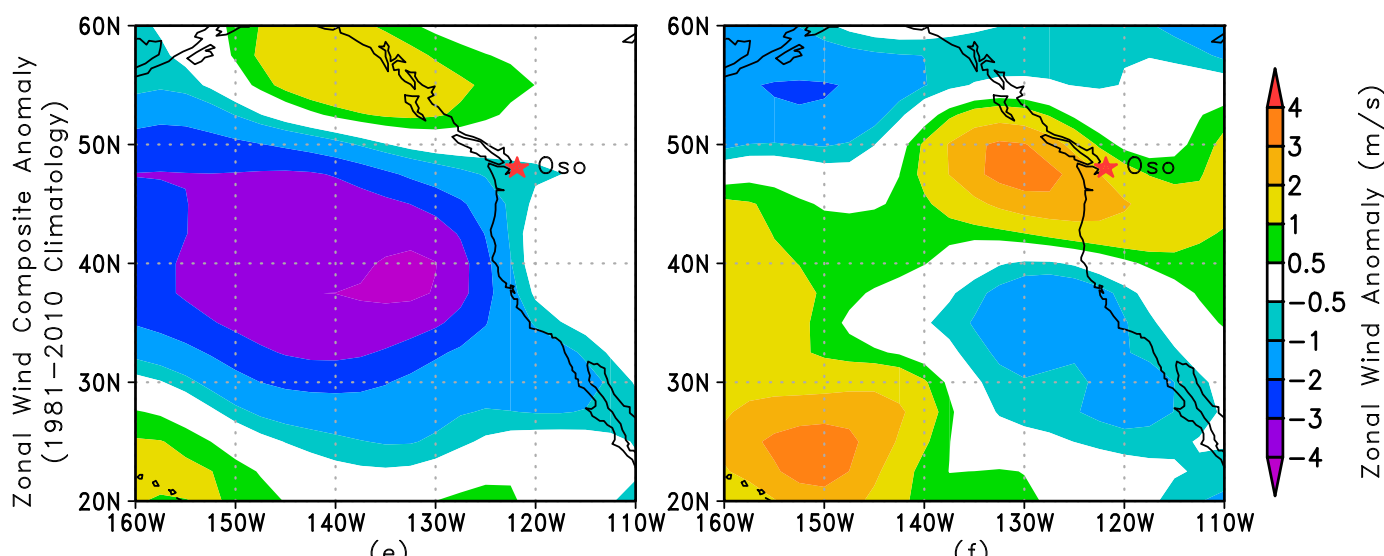

FIG. 2. Anomalies from climatology for (a),(b) 500-hPa geopotential height (m); (c),(d) precipitable water $\left(\mathrm{kg} \mathrm{m}^{-2}\right)$; and (e),(f) zonal wind ( $\mathrm{m} \mathrm{s}^{-1}$ ) from (left) 1 Oct 2013 to 10 Feb 2014 and (right) 11 Feb to 22 Mar 2014. Anomalies are based on CFSR. The flux of large amounts of water vapor into the Pacific Northwest from 11 Feb to 22 Mar 2014 was coupled with stronger-than-normal zonal (east-west) winds.

based on annual maximum accumulations are also shown in Fig. 3 (solid line with plus signs). When considered relative to annual maximum accumulations, the 2014 accumulations are necessarily less unusual. For windows of less than $1 \mathrm{yr}$, the return periods peak at
$2.9 \mathrm{yr}$ for the 42-day accumulation, indicating that the 2014 accumulations were barely above the median annual maximum 42-day precipitation accumulation. Based on the results at Darrington, the precipitation accumulations in the 3-6 weeks prior to the landslide would be 


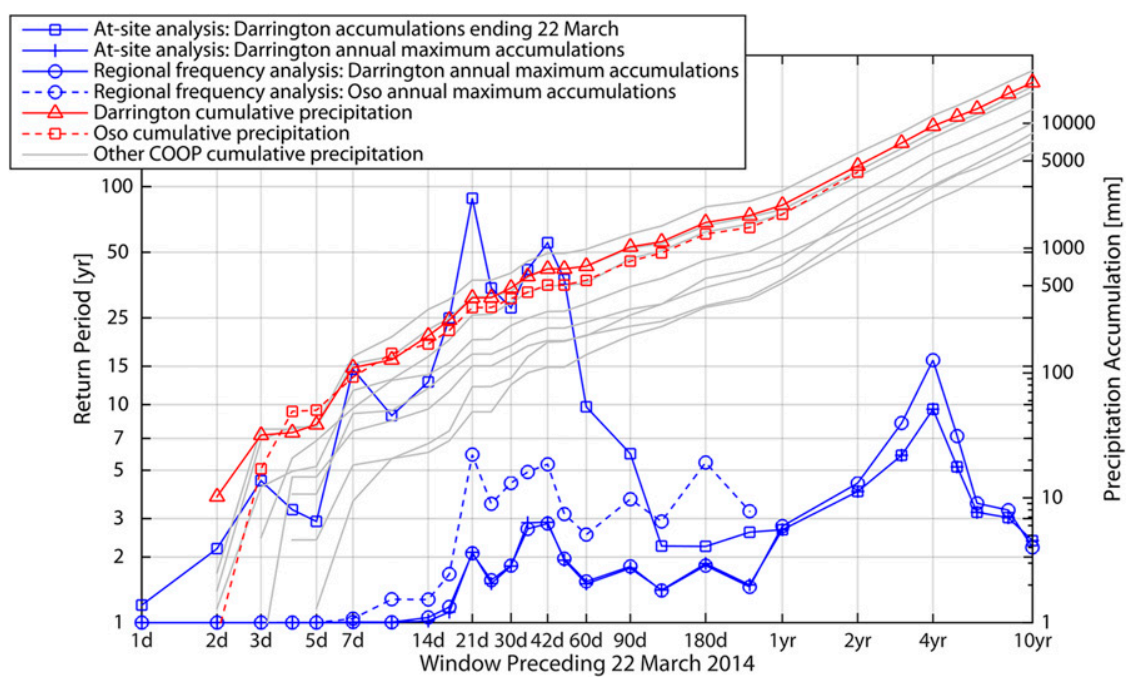

FIG. 3. Precipitation return periods preceding the 2014 Oso landslide. Return periods calculated using several different approaches at the Darrington and Oso gauges are shown in blue. Accumulated precipitation at both gauges is shown in red, and accumulations at the other COOP gauges are shown in gray.

expected to occur sometime in the year on average about once every $3 \mathrm{yr}$.

The solid line with circles in Fig. 3 shows the return periods at Darrington estimated using regional frequency analysis. The results are nearly identical to those from the single-site analysis, with the exception of the multiyear windows, for which the regional frequency analysis yields greater return periods than the at-site analysis $(16 \mathrm{yr}$ versus $9.5 \mathrm{yr}$ for the 4 -yr accumulation). While the use of regional frequency analysis is often advocated to improve the robustness of the estimated return periods (see, e.g., Hosking and Wallis 2005), in this case there was not a great difference between the at-site and regional return periods. For the Oso precipitation gauge, the return periods are shown as the dashed line with circles in Fig. 3. The return periods are greater than those estimated at Darrington, with a peak return period of $5.3 \mathrm{yr}$ for the 21-day window. While higher, the pattern and magnitudes of the return periods at Oso are not dramatically different from those at Darrington.

\section{d. Soil moisture}

Reconstructed soil moisture in March 2014 was above the median daily value for the entire month and exceeded or was close to the $10-y r$ return period for the 10 days preceding the landslide (Fig. 4; note that soil moisture return periods are given for specific dates, rather than relative to the entire year). The maximum came on 16 March, with a return period of about $43 \mathrm{yr}$, slightly less than the maximum of record for that date. On 22 March, the soil moisture return period was about
10 yr. Soil moisture remained more or less constant (with slight variations in response to wet periods) until about a month after the landslide, and then decreased rapidly with the onset of the dry season (not shown). The reconstructed soil moisture reflects the precipitation in the wet period prior to the landslide, as soil moisture responds roughly to accumulated precipitation in the prior months, minus runoff and evapotranspiration. The signature of the dry early winter period is also evident in Fig. 4, as soil moisture was slightly below the median prior to the beginning of the wet period on 11 February.

\section{Discussion and conclusions}

Precipitation in the 21-42 days prior to the Oso landslide was heavy, reflecting the transition during the second week of February to strong onshore flow and anomalously high precipitable water over the region. We estimate that the 21-day accumulations had a recurrence interval of $2.1 \mathrm{yr}$ when compared to annual maxima. However, when compared to only windows ending on 22 March, the peak return period was much larger $(88 \mathrm{yr})$. This reflects the fact that heavy precipitation tends to occur earlier in the water year, typically from November through January. At the two precipitation gauges nearest to the landslide, the accumulated 21-day precipitation was $300-400 \mathrm{~mm}$. We also found a second multiyear maximum for the $4 \mathrm{yr}$ prior to the landslide. A regional analysis yielded essentially the same results as examination of individual gauges. 


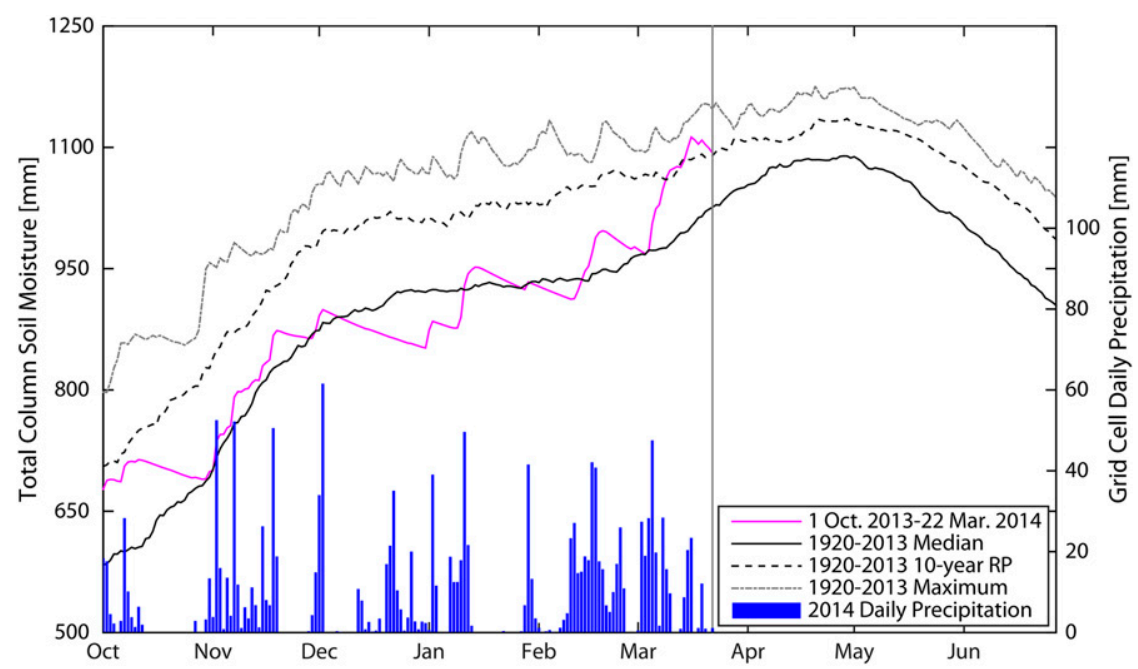

FIG. 4. Reconstructed soil moisture for the VIC grid cell that encompasses the Oso landslide site. Modeled daily soil moisture for water year 2014 is compared to the daily median, 10-yr return period value, and max soil moisture for 1920-2013. Soil moisture is given as total water in the gridcell soil column.

Soil moisture reconstructed from a regional model was anomalously high, in excess of the 10 -yr return period just prior to the landslide. Six days prior to the landslide, soil moisture was at its water year 2014 maximum, with an estimated return period for that date of about $43 \mathrm{yr}$. An examination of groundwater storage inferred from summer base flow analysis was inconclusive (see SM4).

While the precipitation observed leading up to the 2014 Oso landslide was heavy, based on the return periods estimated here, the 21-42-day precipitation accumulations would be expected to occur as often as every $3 \mathrm{yr}$, or no more rarely than every 5-6yr. This heavy precipitation occurred in the context of a $4-\mathrm{yr}$ period of above-average precipitation. It is noteworthy that the period of high precipitation in the weeks before the landslide came near the end of the seasonal wet period, when soil moisture (arguably a better indicator of hazard than precipitation alone) was already high. This is one reason why soil moisture return periods exceed the unconditional (relative to annual maxima) precipitation return periods in the weeks leading up to the slide.

We did not examine the mechanisms that caused the landslide; such analyses are left to others. However, by placing hydroclimatic conditions during the event in historical context, our analysis should contribute to a better understanding of the events leading to the landslide.

Acknowledgments. Support for the lead author was provided by a University of Washington Valle Scholarship.
Additional funding was provided to the U.S. Geological Survey by the Federal Emergency Management Agency.

\section{REFERENCES}

Benda, L., G. W. Thorsen, and S. Bernath, 1988: Report of the ID Team Investigation of the Hazel Landslide on the North Fork of the Stillaguamish River. Department of Natural Resources Rep. F.P.A. 19-09420, 13 pp.

Dragovich, J. D., B. W. Stanton, W. S. J. Lingley, G. A. Greisel, and M. Polenz, 2003: Geologic map of the Mount Higgins 7.5minute quadrangle, Skagit and Snohomish Counties, Washington. Washington State Department of Natural Resources. [Available online at http://wa.water.usgs.gov/data/ger_ofr200312_geol_map_mounthiggins_24k.pdf.]

Haugerud, R., 2014: Preliminary interpretation of pre-2014 landslide deposits in the vicinity of Oso, Washington. USGS OpenFile Rep. 2014-1065, 4 pp. [Available online at http://pubs. usgs.gov/of/2014/1065/pdf/ofr2014-1065.pdf.]

Hosking, J. R. M., and J. R. Wallis, 2005: Regional Frequency Analysis: An Approach Based on L-Moments. Cambridge University Press, 244 pp.

Iverson, R. M., 2000: Landslide triggering by rain infiltration. Water Resour. Res., 36, 1897-1910, doi:10.1029/2000WR900090.

— , and Coauthors, 2015: Landslide mobility and hazards: implications of the 2014 Oso disaster. Earth Planet. Sci. Lett., 412, 197-208, doi:10.1016/j.epsl.2014.12.020.

Jibson, R. W., 1992: The Mameyes, Puerto Rico, landslide disaster of October 7, 1985. Rev. Eng. Geol., 9, 37-54, doi:10.1130/ REG9-p37.

Keaton, J. R., J. Wartman, S. Anderson, J. Benoit, J. DelaChapelle, R. Gilbert, and D. R. Montgomery, 2014: The 22 March 2014 Oso Landslide, Snohomish County, Washington. Geotechnical Extreme Events Reconnaissance Rep., 186 pp. [Available online at http://snohomishcountywa.gov/DocumentCenter/View/ 18180.] 
Liang, X., D. P. Lettenmaier, E. F. Wood, and S. J. Burges, 1994: A simple hydrologically based model of land surface water and energy fluxes for general circulation models. J. Geophys. Res., 99, 14 415-14 428, doi:10.1029/94JD00483.

Miller, D., and J. Sias, 1997: Environmental factors affecting the Hazel landslide. M2 Environmental Services Rep., 56 pp. [Available online at www.netmaptools.org/Pages/Hazel/ Hazel.pdf.]

__ and _ 1999: Hazel/Gold Basin landslides: Geomorphic review draft report. M2 Environmental Services Rep., 25 pp. [Available online at www.nws.usace.army.mil/Portals/27/docs/civilworks/ projects/Hazel-GoldBasinLandslidesGeomorphicReviewDraft. pdf.]
Saha, S., and Coauthors, 2010: The NCEP Climate Forecast System Reanalysis. Bull. Amer. Meteor. Soc., 91, 1015-1057, doi:10.1175/2010BAMS3001.1.

Shannon, W. D., 1952: Report on slide on North Fork Stillaguamish River near Hazel, Washington. Washington State Dept. of Game/Dept. of Fisheries Rep., 46 pp.

Tabor, R. W., D. B. Booth, J. A. Vance, and A. B. Ford, 2002: Geologic map of the Sauk River 30- by 60-minute quadrangle, Washington. USGS, Geologic Investigation Series I-2592, 67 pp. [Available online at http://pubs.usgs.gov/imap/i2592/.]

Thorsen, G. W., 1989: Landslide provinces in Washington. Engineering Geology in Washington, R.W. Galster, Ed., Washington Division of Geology and Earth Resources Bulletin 78, Vol. 1, 71-89. 